\title{
SYSTEMIC LUPUS ERYTHEMATOSUS
}

\section{A REPORT ON TWELVE CASES TREATED WITH QUINACRINE (ATABRINE $\left.{ }^{\circledR}\right)^{*}$ AND CHLOROQUINE (ARALEN $\left.{ }^{\circledR}\right)^{*}$}

\author{
BY \\ S. K. CONNER \\ From the Section on Internal Medicine of the Lois Grunow Memorial Clinic, Phoenix, Arizona
}

(RECEIVED FOR PUBLICATION DECEMBER 5, 1956)

Many reports can be found in the literature expounding the value of quinacrine and chloroquine (Mepacrine hydrochloride B.P.) in the treatment of chronic or discoid lupus erythematosus (Cramer and Lewis, 1952; Sawicky, Kanof, Silverberg, Braitman, and Kalish, 1952; O'Leary, Brunsting, and Kierland, 1953; Shee, 1953; Rhodes and Allende, 1954; Rogers and Finn, 1954).

More recently the use of hydroxychloroquine $\dagger$ has been described by several authors (Goldman, L. (in discussion of Stegmaier) 1955; Mullins, Kirk, and Shapiro, 1955; Kierland, R. (in discussion of Laymon) 1955; Lewis and Frumess, 1956; Bennett and Rees, 1956; Mullins, Watts, and Wilson, 1956; Cornbleet, 1956).

References to its use in systemic lupus erythematosis are less numerous (Kierland, Brunsting, and O'Leary, 1953; Dubois, 1954; Glaser, 1953; Gilbert, 1955; Dubois, 1955, 1956a, 1956b; Haserick, 1955, 1956; Shulman and Harvey, 1956; Medical Times, 1956), and it has in fact been condemned by some authors because it is thought to aggravate the systemic manifestations. Whether this impression is true or false remains to be proved by a larger number of these cases adequately treated with Atabrine. The present series would indicate that its value is as great and possibly even greater in systemic lupus erythematosus than in the chronic form.

Systemic lupus erythematosus is well known to be equal to syphilis as the great imitator; its varied symptoms may wax and wane, or progress rapidly,

\footnotetext{
* The Atabrine and Aralen used in this study were kindly supplied by the Medical Research Department of Winthrop Laboratories, N.Y., by the

† Plaquenil ${ }^{\circledR}$, Winthrop Laboratories.
}

may be severe or mild, and may involve single or multiple organ systems of the body.

In systemic lupus erythematosus, the principal pathological alterations are found in the collagen fibres of the connective tissue, and it is therefore grouped with rheumatoid arthritis, rheumatic fever, polyarteritis, scleroderma, and dermatomyositis, under the heading of collagen disease. These pathological findings are not necessarily specific and may occur in other circumstances. There are dissimilarities as well as similarities among the various so-called collagen diseases. The similarities suggest that each is merely a different manifestation of the same basic disease, but the dissimilarities are striking enough to prevent the acceptance of this idea at the present time. Systemic lupus erythematosus may simulate various members of this group and the clinical and pathological findings sometimes suggest the occurrence of two or more diseases in the same patient. The clinical features may be so varied and blended that it is impossible to determine the basic underlying disease process. Even post mortem examination may do no more than suggest undifferentiated collagen disease.

\section{Diagnosis}

There is no established criterion for the diagnosis of systemic lupus erythematosus, and until the advent of the "L.E." cell phenomenon the majority of patients went undiagnosed until the post mortem examination. Since this laboratory finding has become available, a marked rise in recognized cases has occurred. Systemic cases may occur without this phenomenon ever being found, and it is also presently recognized that the skin lesions are less 
frequently observed, possibly because of the physician's continued awareness which results in earlier diagnosis of suspicious cases presenting such variable findings as arthritis, arthralgia, falsepositive serology, neutropenia, fever, general debility, and L.E. cells.

Several clinical features of systemic lupus erythematosus merit comment; some may be absent or only faintly present in individual cases. Particularly interesting are joint manifestations, which are quite variable, with periodic exacerbations and remissions of both subjective and objective complaints. The former may range from mild discomfort of aching and stiffness to complaints of severe poly-migratory aching, soreness, tenderness, stiffness, and weakness. Usually the subjective complaints are disproportionate to the objective findings. On the other hand there may be acute peripheral joint involvement, multiple or localized, with varying degrees of swelling, redness, tenderness, and heat, which occasionally resemble rheumatic fever or rheumatoid arthritis with marked joint deformity, ankylosis, contractures, and muscle atrophy. The patient may be treated for several years as a case of typical rheumatoid arthritis before the nature of his disease is determined. Arthritis or arthralgia occurs in approximately 80 or 90 per cent. of cases of systemic lupus erythematosus and often is the initiating and presenting complaint. Such findings may be easily misleading. Arthritic complaints may be the only indication of illness for a long time and be so prominent that other manifestations are obscured. When $x$-ray changes of joints are present, they may be considered typical of rheumatoid arthritis. Purpura is frequently a manifestation of lupus erythematosus; but, in cases that are receiving, or have received, steroid therapy, it may be a misleading symptom. Skin lesions may vary in appearance, extent, and severity, but are most commonly located on the exposed surfaces (the face, the V-area of the neck, and the hands). Besides the more commonly seen lesions, one may encounter ulcerations of the skin, nodules, skin atrophy, almost scleroderma-like in appearance, over the digits (which is frequently associated with Raynaud's syndrome), and subcutaneous oedema of the extremities which may be associated with muscular symptoms very similar to dermatomyositis.

Involvement of the cardiovascular system is frequent, consisting most notably of pericarditis, endocarditis, or myocarditis, and characterized by tachycardia, friction rub, murmurs, cardiac enlargement, abnormal electrocardiograph findings, and decompensation with its sequelae.

As previously mentioned, any organ system of the body may be involved during the process of this disease, giving multiple and varied manifestations, and resembling many different pathological conditions.

\section{Material}

Twelve cases (seven from private practice and five from the arthritic clinic at the Maricopa County Hospital) form the basis of this report.

Others have not been included because of loss of contact, even though the initial response was encouraging, or because of inability to demonstrate the L.E. cell phenomenon, although marked benefit had been received from the use of Atabrine, with relief of the objective and subjective findings consistent with systemic lupus erythematosus.

In order to be more critical of this form of therapy, the results herein reported are supported in every instance by the finding of L.E. cells in the peripheral blood or bone marrow, or both. No presumptive cases were included, even though the clinical features and course suggested a diagnosis of systemic lupus erythematosus.

During the past 2 years bone marrow preparations or biopsies of the skin or lymph nodes have not been performed, routinely.

It is realized that L.E. cells are not universally demonstrated in patients having this disease, and in certain rare instances L.E. cells may occur without the disease being present. Nevertheless, it may be assumed that the L.E. cell phenomenon has a high degree of specificity for systemic lupus erythematosus.

In all of the cases included, several of the systemic manifestations, both subjective and objective, were present. The most notable of the former were variable arthralgia, weakness, anorexia, paraesthesia, and dyspnoea. Objective findings included skin rash, serositis, oedema, purpura, ulcerations of nodules and skin, arthritis, and additional laboratory findings such as leucopenia, secondary anaemia, elevated erythrocyte sedimentation rate, false-positive serology, urinary abnormalities, and blood protein changes.

In one case, changes in the left parotid gland prompted a biopsy and the findings were consistent with the diagnosis of Mikulicz's disease. In this case both bone marrow and peripheral blood studies revealed the presence of numerous L.E. cells. No steroid therapy was used in this case and the patient responded dramatically to Atabrine with complete relief of systemic manifestations and reduction of the parotid gland to normal size.

\section{Method of Treatment}

The method of treatment varied with the severity of the clinical manifestations.

Five cases were first begun on steroid therapy or had already been placed on steroid therapy, consisting usually of ACTH or prednisone. Usually by the second or third day after the institution of steroid therapy, when systemic manifestations had begun to lessen, Atabrine 1.5 gr. (100 mg.) three times a day, was begun. Withdrawal of steroid therapy was undertaken as rapidly as possible, 
being usually spread over approximately 2 to 4 weeks. In three of these cases, which had been on steroid therapy previously, it was possible to reduce the dosage considerably below that which had been necessary for maintenance on previous occasions. One, that had been on a large dosage schedule of prednisone, had been gradually reduced to $7 \cdot 5 \mathrm{mg}$. daily with no evidence of exacerbation. The other two have at infrequent intervals received ACTHAR-gel or zinc-cortrophin of approximately $\mathbf{4 0}$ units for 1 to 3 days to control minor flare-ups or as support against possible other influencing factors.

In six patients Atabrine therapy was given without steroid therapy, beginning with $1.5 \mathrm{gr}$. (100 mg.) three times daily, p.c., for 2 to 3 weeks, and reducing to $1.5 \mathrm{gr}$. (100 mg.) twice daily p.c., for approximately 2 weeks, depending upon the response of the systemic manifestations; thereafter, $1 \cdot 5 \mathrm{gr}$. was given daily for an indefinite period of time, ranging from 4 to 32 months.

One case received chloroquine with control of symptoms.

\section{Results}

During the period of observation of these twelve cases of systemic lupus erythematosus, which ranged from 4 to 32 months, their course appeared to be much more favourable than one would expect in this form of illness. The clinical and laboratory findings in these twelve cases are set out in Tables I and II.

The grade of response shown in Table III is on the basis of 0 to ++++ , from no response to complete relief or remission. This does not include the residual joint deformity and limitation of motion but does indicate the degree of relief from joint pain, tenderness, and swelling.

In Table I, the severity of systemic manifestations is graded from + to ++++ , from slight to severe symptoms.

Table III (overleaf) shows that all experienced adequate relief of symptoms, both objectively and subjectively, as well as laboratory improvement in the white blood count and hematocrit, and usually a decrease in the erythrocyte sedimentation rate and the number of L.E. cells found. Complications were minor. Pseudo-icterus, which occurred in eleven of the twelve cases, was not considered a complication and was not distressing to the patient, considering the amount of improvement derived.

Notable skin rash occurred in one patient, involving the lower extremities from the knees down; this cleared in 8 to 10 weeks after withdrawal of Atabrine, and in view of its peculiar distribution was

CLINICAL FINDINGS

\begin{tabular}{|c|c|c|c|c|c|c|c|}
\hline \multirow{2}{*}{ Case } & \multirow{2}{*}{$\begin{array}{l}\text { Age } \\
\text { (yrs) }\end{array}$} & \multirow[b]{2}{*}{ Sex } & \multirow{2}{*}{$\begin{array}{l}\text { Duration } \\
\text { of } \\
\text { Symptoms } \\
\text { (yrs) }\end{array}$} & \multirow{2}{*}{$\begin{array}{l}\text { Systemic } \\
\text { Findings }\end{array}$} & \multicolumn{3}{|c|}{ Arthritis Symptoms } \\
\hline & & & & & Joints & Skin & Arthralgia \\
\hline 1 & 59 & $\mathbf{M}$ & 35 & $+t+$ & Symmetrical involvement & Atrophy over digits & $+++\cdots$ \\
\hline 2 & 46 & $\mathrm{~F}$ & 20 & $+t+$ & $\begin{array}{l}\text { Symmett ical involvement } \\
\text { Typical rheumatoid arthritis }\end{array}$ & Mild atrophy over digits & $++1+$ \\
\hline 3 & 45 & $\mathbf{M}$ & 16 & + & $\begin{array}{l}\text { Symmetrical involvement } \\
\text { Typical rheumatoid arthritis }\end{array}$ & Mild at rophy over digists & $4+2$ \\
\hline 4 & 61 & F & 15 & +++ & $\begin{array}{l}\text { Symmetrical involvement } \\
\text { Typical rheumatoid arthritis }\end{array}$ & Mild atrophy over digits & $+t+t$ \\
\hline 5 & 29 & $\mathbf{F}$ & 4 & $t+t+$ & Episodic fingers and knees & $\begin{array}{l}\text { Butterfly of face and V of neck } \\
\text { Severe with scarring }\end{array}$ & +++ \\
\hline 6 & 25 & $\mathbf{F}$ & 1 & ++++ & $\begin{array}{l}\text { Symmetrical swelling, tender- } \\
\text { ness } \\
\text { Limited motion }\end{array}$ & No lesions & $\begin{array}{l}++++ \\
\text { Generalized }\end{array}$ \\
\hline 7 & 39 & $\mathbf{F}$ & 2 & ++ & - & $\begin{array}{l}\text { Small scaling lesions on } \\
\text { forehead }\end{array}$ & $\begin{array}{c}++ \\
\text { Generalized }\end{array}$ \\
\hline 8 & 26 & $\mathbf{F}$ & 9 & ++++ & $\begin{array}{l}\text { Symmetrical contractures } \\
\text { fingers and toes (subluxation) }\end{array}$ & $\begin{array}{l}\text { Raynaud's syndrome } \\
\text { Atrophy }\end{array}$ & $+t+$ \\
\hline 9 & 32 & $\mathbf{F}$ & 8 & $++t+$ & $\begin{array}{l}\text { Symmetrical involvement } \\
\text { Typical rheumatoid arthritis }\end{array}$ & History of face rash 8 yrs ago & $+t+t$ \\
\hline 10 & 38 & $F$ & 19 & $+t+t$ & $\begin{array}{l}\text { Symmetrical involvement } \\
\text { Typical rheumatoid arthritis }\end{array}$ & $\begin{array}{l}\text { Draining nodules, ulcerations, } \\
\text { lower lateral third of right leg }\end{array}$ & $+t+t$ \\
\hline 11 & 34 & $\mathbf{F}$ & 7 & $++t$ & $\begin{array}{l}\text { Symmetrical involvement } \\
\text { Typical rheumatoid arthritis } \\
\text { Mutilating }\end{array}$ & - & $+1+t$ \\
\hline$\overline{12}$ & 61 & $\mathbf{M}$ & $6 \frac{1}{2}$ & ++ & None & None & $+t+$ \\
\hline
\end{tabular}


possibly a contact dematitis. The patient has now received no Atabrine therapy for approximately 10 months and has continued free of subjective or objective manifestations of lupus erythematosus.

It has not been necessary to resort to steroid therapy in those patients initially begun on Atabrine and in each instance when this medication was discontinued and the patient noticed signs of an exacerbation of the systemic manifestations, the symptoms were controlled in 7 to 21 days by the re-institution of Atabrine therapy.

One patient (Case No. 9), now approximately 8 months pregnant, recently experienced a minor flare-up of the systemic manifestations of lupus erythematosus at approximately the seventh month of gestation. At that time she had not received any Atabrine for approximately one year, and the fresh symptoms were controlled by Atabrine in approximately 2 weeks. She is to continue the Atabrine until an undetermined period after her delivery.

Some of those receiving steroid therapy had subjective and objective findings of disease activity and were more adequately controlled and comfortable on Atabrine therapy in conjunction with steroid therapy; at the same time maintenance steroid therapy was reduced considerably, which had not been possible previously.

Four cases showed a reduction in the erythrocyte sedimentation rate to normal after Atabrine therapy. Four cases showed false-positive serology at some time during the course of their illness.

\section{Complications}

The incidence of complications arising from the use of Atabrine is low and consists in the main of various skin eruptions, such as lichenoid dermatitis, eczematoid dermatitis, exfoliative dermatitis, and hyperkeratosis. These are not necessarily serious, but the discomfort to the patient may be severe and at times rather prolonged. Other less frequent complications are toxic psychosis, polyneuritis, granulocytosis, aplastic anaemia, hepatitis, and relatively minor symptoms of nausea, flatulence, diarrhoea, and occasional vomiting.

In the present series it was noted that occasionally pseudo-icterus of the sclerae occurred; however, liver function tests were performed and found to be normal.

TABLE II

LABORATORY FINDINGS

\begin{tabular}{|c|c|c|c|c|c|c|}
\hline $\begin{array}{l}\text { Case } \\
\text { No. }\end{array}$ & $\begin{array}{l}\text { White } \\
\text { Blood } \\
\text { Cells }\end{array}$ & L.E. Cells & Serology & $\begin{array}{c}\text { Erythrocyte } \\
\text { Sedimentation } \\
\text { Rate } \\
\text { (Wintrobe) } \\
\text { (mm./hr) }\end{array}$ & Urine & $X$-Rays \\
\hline 1 & 3,800 & $+t+t$ twice & Negative & 32 & $\begin{array}{l}\text { Micro. } \\
\text { haematuria }\end{array}$ & $\begin{array}{l}\text { Narrowing inter-phalangeal joint } \\
\text { spaces and osteoporosis }\end{array}$ \\
\hline 2 & 2,150 & $\begin{array}{l}\text { Bone marrow }++++3 / 55 \\
\text { Peripheral blood }++++\end{array}$ & $\begin{array}{l}\text { Weakly positive } \\
(1950)\end{array}$ & 40 & Negative & Typical of rheumatoid arthritis \\
\hline 3 & 5,500 & $\begin{array}{l}\text { Peripheral blood }+ \\
\text { twice }\end{array}$ & $\begin{array}{l}\text { Weakly positive } \\
(1930,1950)\end{array}$ & 37 & $\begin{array}{l}\text { Micro. } \\
\text { haematuria }\end{array}$ & Typical of rheumatoid at thritis \\
\hline 4 & 5,900 & $\begin{array}{l}\text { Peripheral blood }++++ \\
\text { twice }\end{array}$ & Negative & 43 & $\begin{array}{l}\text { Micro. } \\
\text { haematuria }\end{array}$ & Typical of rheumatoid arthritis \\
\hline 5 & 2,800 & $\begin{array}{l}\text { Peripheral blood }++++ \\
\text { once; suspicious once }\end{array}$ & Negative & 28 & $\begin{array}{l}\text { Micro. } \\
\text { haematuria; } \\
\text { Albuminuria }\end{array}$ & $\begin{array}{l}\text { Cardiac enlargement with } \\
\text { decompensation }\end{array}$ \\
\hline 6 & 8,550 & $\begin{array}{l}\text { Peripheral blood }++t+ \\
(30-4-56)\end{array}$ & Negative & 23 & - & Normal \\
\hline 7 & 5,400 & $\begin{array}{l}\text { Peripheral blood }+ \\
(14-4-55) \text {; suspicious } \\
(17-7-56)\end{array}$ & $\begin{array}{l}\text { Positive (1954) } \\
\text { Negative since }\end{array}$ & $\begin{array}{c}22 \\
\text { (Cutler) } \\
(12-5-54)\end{array}$ & - & - \\
\hline 8 & 4,500 & $\begin{array}{l}\text { Peripheral blood }+ \\
\text { three times }\end{array}$ & Negative & $\begin{array}{c}23 \\
\text { (Cutler) }\end{array}$ & - & 一 \\
\hline 9 & 2,300 & $\begin{array}{l}\text { Peripheral blood }++++ \\
\text { three times }\end{array}$ & $\begin{array}{l}\text { Positive on } \\
\text { occasions }\end{array}$ & 38 & $\begin{array}{l}\text { Micro. } \\
\text { haematuria }\end{array}$ & - \\
\hline 10 & 4,800 & $\begin{array}{l}\text { Peripheral blood }+ \\
\text { four times }\end{array}$ & Negative & $\begin{array}{c}20 \\
\text { (Cutler) }\end{array}$ & Negative & - \\
\hline 11 & 10,350 & $\begin{array}{l}\text { Peripheral blood }++++ \\
\quad(11-4-55) ;+(16-7-55)\end{array}$ & Negative & 32 & $\begin{array}{l}\text { Occasional } \\
\text { RBC }\end{array}$ & $\begin{array}{l}\text { Hands typical of rheumatoid } \\
\text { arthritis. Changes }++t+\end{array}$ \\
\hline 12 & 7,700 & $\begin{array}{l}\text { Peripheral blood }+ \\
\text { three times }\end{array}$ & Negative & 36 & $\begin{array}{l}\text { Occasional } \\
\text { RBC }\end{array}$ & $\begin{array}{l}\text { Right hand demineralization } \\
\text { of epiphyses }\end{array}$ \\
\hline
\end{tabular}


TABLE III

RESPONSE TO TREATMENT

\begin{tabular}{|c|c|c|c|c|c|c|}
\hline $\begin{array}{l}\text { Case } \\
\text { No. }\end{array}$ & Duration of Therapy & $\begin{array}{l}\text { White } \\
\text { Blood } \\
\text { Cells }\end{array}$ & L.E. Cells & $\begin{array}{c}\text { Erythrocyte } \\
\text { Sedimentation } \\
\text { Rate } \\
(\mathrm{mm} . / \mathrm{hr})\end{array}$ & $\begin{array}{l}\text { Toxic } \\
\text { Reaction }\end{array}$ & Status \\
\hline 1 & $5 \mathrm{mths}$ & . 7,800 & Negative & 32 & $\begin{array}{l}\text { Dermatitis, } \\
\text { hands }\end{array}$ & $\begin{array}{l}++ \text { Improved motion. No joint pain } \\
\text { Rash not increased in past month while } \\
\text { on Atabrine }\end{array}$ \\
\hline 2 & $\begin{array}{l}7 \mathrm{mths} \\
\text { None for past } 10 \mathrm{mths}\end{array}$ & 3,500 & Positive & 34 & $\begin{array}{l}\text { ? Dermatitis, } \\
\text { knees down }\end{array}$ & $\begin{array}{l}++++ \text { Clinical improvement } \\
\text { No systemic complaints }\end{array}$ \\
\hline 3 & $3 \mathrm{mths}$ & - & - & - & None & 0 No change \\
\hline 4 & $7 \mathrm{mths}$ & 6,000 & Negative & 38 & None & $\begin{array}{l}+++ \text { Clinical subjective and objective } \\
\text { improvement }\end{array}$ \\
\hline 5 & $2 \frac{1}{2} \mathrm{mths}$ & 10,800 & - & 15 & None & 5 mg. Meticorten daily, is being withdrawn \\
\hline 6 & $\begin{array}{l}3 \mathrm{mths} \\
\text { Zinc-cortrophin } 12 \text { days } \\
\text { Meticorten } 6 \text { weeks }\end{array}$ & & & & None & $++-1+$ \\
\hline 7 & $\begin{array}{l}\text { Intermittent Aralen } 15 \mathrm{mths} \\
\text { No steroid }\end{array}$ & 7,500 & Suspicious & 8 & None & $\begin{array}{l}\text { Objected to Atabrine because of possible } \\
\text { pseudo-icterus }\end{array}$ \\
\hline 8 & Intermittent 2 yrs & 7,200 & $\begin{array}{l}\text { Negative } \\
(6-23-56)\end{array}$ & - & ? Nausea & $\begin{array}{l}\text { Symptoms controlled by Atabrine in } \\
3 \text { to } 6 \text { weeks } \\
\text { Relapse } 3-5 \text { mths after discontinuing }\end{array}$ \\
\hline 9 & $\begin{array}{l}\text { Intermittent } 2 \text { yrs } \\
\text { ACTH initial, withdrawn } \\
\text { over 2-mth period }\end{array}$ & 9,500 & $\begin{array}{l}\text { Positive } \\
(4-7-56)\end{array}$ & 40 & None & $\begin{array}{l}\text { Atabrine controlled flare-up in } 2 \text { to } 3 \text { wos: } \\
\text { now } 8 \mathrm{mths} \text { pregnant and on Atabrine }\end{array}$ \\
\hline 10 & $\begin{array}{l}\text { Intermittent } 2 \frac{1}{2} \text { yrs } \\
\text { No steroid }\end{array}$ & 4,800 & Negative & 5 & None & $\begin{array}{l}\text { Healed ulceration. Minor flare-up con- } \\
\text { trolled by Atabrine. }\end{array}$ \\
\hline 11 & $\begin{array}{l}\text { Aralen } 16 \mathrm{mths} \\
\text { Meticorten } 4 \text { wks not below } \\
10 \mathrm{mg} \text {. daily. } \\
\text { Atabrine } 14 \mathrm{mths} \\
\text { Meticorten } 0 \text { to } 2.5 \mathrm{mg} \text {. daily }\end{array}$ & 12,100 & Negative & 21 & None & Atabrine and $0-2 \cdot 5 \mathrm{mg}$. Meticorten dail \\
\hline 12 & Atabrine and ASA $18 \mathrm{mths}$ & 10,300 & Negative & 42 & None & $\begin{array}{l}++ \text { Equivocal. No progression. Less } \\
\text { arthralgia. Less aspirin needed }\end{array}$ \\
\hline
\end{tabular}

Minor gastro-intestinal disturbances of anorexia and nausea occurred in two cases; in neither was discontinuance of the drug necessitated, but occasionally a reduction in dosage was necessary.

No cases of granulocytosis developed and in those which originally exhibited neutropenia the blood count rose to near normal or normal after the institution of Atabrine therapy.

The possibility of the occurrence of complications must be kept in mind, but at the same time one must remember the natural course of systemic lupus erythematosus, as well as its grave prognosis, and the possible relief afforded by Atabrine should not be denied these patients.

\section{Summary}

(1) The low incidence of complications from Atabrine therapy and its beneficial effects in a small series of twelve cases suggest that Atabrine may eventually prove superior to steroid therapy in the treatment of systemic lupus erythematosus, with respect to life expectancy, complications, and morbidity.

(2) Pregnancy in a patient with lupus erythematosus is usually accompanied by an exacerbation of symptoms. Previous reports show that Atabrine may be given with no untoward effect on the foetus. In one case in this series, Atabrine is being administered to such a patient with control of minor exacerbations of lupus erythematosus.

(3) It is felt that acute systemic lupus erythematosus is not a contraindication to the use of Atabrine, but quite the contrary. When Atabrine is used in conjunction with steroid therapy, better results may be obtained if steroid therapy is given to control the severe, acute manifestations and then withdrawn in 2 to 4 weeks with periodic administration if necessary.

(4) In seven of the twelve cases in the present series, Atabrine was used alone and gave adequate control of symptoms. 
(5) In suspected cases of systemic lupus erythematosus, multiple L.E. cell preparations should be performed at frequent intervals to obtain a higher percentage of positive findings, as the results suggest that L.E. cells are only intermittently demonstrable even in proven cases.

\section{REFERENCES}

Bennett, J. H., and Rees, R. B. (1956). "Plaquenil Sulphate in Treatment of Lupus Erythematosus and Light Sensitivity Eruptions." Presented at the California Medical Association Meeting, Los Angeles, 1956.

Cornbleet, T. (1956). A.M.A. Arch. Derm., 73, 572.

Cramer, J. A., and Lewis, G. M. (1952). J. invest. Derm., 19, 393.

Dubois, E. L. (1954). Arch. intern. Med., 94, 131.

(1955). A.M.A. Arch. Derm., 71, 570

(1956a). Ann. intern. Med., 45, 163.

(1956b). J. Amer. med. Ass., 161, 427.

Gilbert, F. I., Jr. (1955). Hawaii med. J., 14, 503.

Glaser, G. H. (1953). Neurology, 5, 751.

Goldman, L. (1955). In discussion of O. C. Stegmaier: A.M.A. Arch. Derm., 71, 416.

Haserick, J. R. (1955). J. chron. Dis., 1, 317.

(1956). Conn. St. med. J., 20, 617.

Kierland, R. (1955). In discussion of C. W. Laymon. A.M.A. Arch. Derm., 72, 381 .

—_, Brunsting, L. A., and O'Leary, P. A. (1953). Ibid., 68, 651.

Lewis, H. M., and Frumess, G. M. (1956). Ibid., 73, 576.

Medical Times (1956), 84, 111.

Mullins, J. F., Kirk, J. M., and Shapiro, E. M. (1955). Sth. med. J. 48, 732 .

_, Watts, F. L., and Wilson, C. J. (1956). J. Amer. med. Ass., 161,879 .

O'Leary, P. A., Brunsting, L. A., and Kierland, R. R. (1953). A.M.A Arch. Derm. Syph., 67, 633.

Rhodes, B. L., and Allende, M. F. (1954). Calif. Med., 80, 70

Rogers, J., and Finn, O. A. (1954). A.M.A. Arch. Derm. Syph., 70,61 .

Sawicky, H. H., Kanof, N. B., Silverberg, M. G., Braitman, M., and Kalish, B. (1952). J. invest. Derm., 19, 397.

Shee, J. C. (1953). Lancet, 2, 201.

Shulman, L. E., and Harvey, A. M. (1956). "Disease-a-Month", May, p. 33. Chicago Year Book Publishers Inc.

\section{Lupus érythemateux généralisé}

\section{RÉSUMÉ}

(1) La proportion minime de complications après le traitement à l'Atabrine et les effets bénéfiques de ce médicament dans une série de douze cas, suggèrent que l'Atabrine peut éventuellement se révéler supérieure à la thérapie stéroïde dans le traitement du lupus érythémateux généralisé en ce qui concerne la survie, les complications et la morbidité.

(2) La grossesse chez une malade atteinte de lupus érythémateux généralisé est d'ordinaire accompagnée d'une exacerbation des symptômes. Des rapports antérieurs montrent que l'Atabrine peut être administrée sans effets facheux sur le foetus. Dans un cas de cette série, le traitement à l'Atabrine d'une telle patiente permet de freiner les exacerbations mineures du lupus érythémateux.

(3) On a l'impression que le lupus érythémateux généralisé aigu ne contraindique pas l'emploi de l'Atabrine, bien au contraire. Quand l'Atabrine est employée de pair avec la thérapie stéroïde, on peut obtenir de meilleurs résultats si la thérapie stéroïde est appliquée pour juguler les manifestations aiguës sévères, puis interrompue après 2 à 4 semaines, avec reprise périodique, si nécessaire.

(4) Dans sept des douze cas de la série considérée, l'Atabrine fur employée seule et permit un contrôle adéquat des symptômes.

(5) Quand on soupçonne un cas de lupus érythémateux généralisé, on devrait faire de multiples préparations de cellules L.E. à des intervalles fréquents, de façon à obtenir un plus grand pourcentage de résultats positifs; les résultats suggérent qu'on ne met en évidence les cellules L.E. que d'une façon intermittente, même dans les cas établis.

\section{Lupus eritematoso generalizado}

\section{Sumario}

(1) La baja incidencia de complicaciones después del tratamiento con Atabrina y los efectos beneficiosos de este medicamento en una serie de doce casos, sugieren que la Atabrina puede revelarse eventualmente superior a la terapia esteroide en el tratamiento del lupus eritematoso generalizado respecto a la sobreviviencia, las complicaciones y la morbidez.

(2) La preñez de una enferma con lupus eritematoso generalizado se acompaña generalmente de una exacerbación de los síntomas. Informes anteriores señalan que se puede administrar la Atabrina sin dañar el feto. En un caso de esta serie el tratamiento con Atabrina de tal enferma permite el control de exacerbaciones menores del lupus eritematoso.

(3) Se cree que el lupus eritematoso generalizado agudo no contraindica el empleo de la Atabrina, sino lo contrario. Al emplear la Atabrina en conjunto con la terapia esteroide, se pueden conseguir los mejores resultados con el empleo de los esteroides para controlar les menifestaciones agudas graves, interrumpiendo la administración de éstos al cabo de 2 a 3 semanas y volviendo a ellos en caso de necesidad.

(4) En siete de los doce casos de la serie considerada, el empleo de la Atabrina sola fué suficiente para controlar los síntomas adecuadamenta.

(5) Al sospechar un caso de lupus eritematoso generalizado, se precisan preparaciones multiples de células L.E. a intervalos frecuentes de manera a conseguir el mayor número de resultados positivos; los resultados sugieren que las células L.E. no se evidencian que de un modo intermitente, hasta en casos establecidos. 